\title{
Qualitative classification of woven fabrics produced from recycled threads of cotton and blends
}

DOI: $10.35530 / \mathrm{IT} .071 .02 .1638$

KALKANCI MIHRIBAN

ABSTRACT - REZUMAT

Qualitative classification of woven fabrics produced from recycled threads of cotton and blends

In this study, shirting fabrics were woven with weft threads produced from blends of recycled cotton fibers, original cotton fibers and original polyester fibers (100\% original cotton, $100 \%$ recycled cotton, $35 \% / 65 \%$ polyester/recycled cotton, $35 \% / 65 \%$ polyester/original cotton, $50 \% / 50 \%$ polyester/recycled cotton, 50\%/50\% polyester/original cotton). The produced fabrics were investigated in terms of fabric defects by using fabric quality control machines after wet treatment procedures have been carried out. The types and numbers of defects detected during quality control were recorded and graded according to Graniteville 78 Fabric Inspection System and were classified accordingly. All fabrics were evaluated in terms of fabric quality.

Keywords: recycled fabric, fabric quality, grading, tailorability

Clasificarea calitativă a țesăturilor produse din fire de bumbac și în amestec reciclate

În acest studiu, țesăturile pentru confecţionarea cămăşilor au fost realizate din fire de bătătură produse din amestecuri de fibre de bumbac reciclate, fibre de bumbac originale și fibre de poliester originale $1100 \%$ bumbac original, $100 \%$ bumbac reciclat, 35\%/65\% poliester/bumbac reciclat, 35\%/65\% poliester/bumbac original, 50\%/50\% poliester/bumbac reciclat, $50 \% / 50 \%$ poliester/bumbac original). Țesăturile produse au fost investigate în ceea ce privește defectele, folosind echipamente de control al calității după ce au fost aplicate operațiile de tratament umed. Tipurile și numărul de defecte detectate în timpul controlului calității au fost înregistrate și clasificate în conformitate cu sistemul de inspecție a țesăturilor Graniteville 78. Toate țesăturile au fost evaluate din punct de vedere calitativ.

Cuvinte-cheie: ţesătură reciclată, calitatea ţesăturii, gradare, adaptabilitate

\section{INTRODUCTION}

For a sustainable life style, several strategies have come to the forefront in the design and production stages of textiles and apparel manufacturing. These strategies are reduce, reuse, energy recovery and recycling. Almost $100 \%$ of textiles are suitable for recycling.

Textile recycling industry is a feasible and economically sustainable industry provided that textile wastes are systemically collected and handled [1]. On the other hand, worn-out textile products should not cause harm to the environment or to human health during their afterlife stage via incineration, decaying or landfilling. The most efficient solution is recycling [2]. In other words, recovering fibers of the worn-out textile products [3]. As the raw materials, machinery, energy type and cost, environmental interactions during processes in the course of production as well as the recyclability of textile products are not the same, it is very difficult to investigate recycling in textiles under one title [4]. In order to recover fibers from textile waste and reuse them in conventional textile processes, the wastes should be open up to fibers and separated. The fibers can be sorted via use of fabric shredders (disintegrators) equipped with thread opening elements. Separation of component fibers following fabric disintegration is the most important step in terms of fiber recovery in waste of blend textile wastes [5]. Depending on the final use, the fibers are also utilized in blends. Following, the fibers are prepared for spinning for weaving or knitting via being cleaned and blended in carding machines [6]. There are many different spinning systems in textile manufacturing. Among the spinning systems, ring, Open-End Rotor spinning, airjet spinning and compact spinning systems are still the widely most used spinning systems [7]. At the same time, recycling mostly takes place in the spinning stage. Open-end rotor spinning system, which allows use of fibers shorter than ring spinning mostly, utilize recycled fibers [8].

Different textile recycling systems have been developed including product recovery, chemical recovery and thermal recovery [9]. A number of research studies have been conducted for investigating properties of threads and fabrics produced from wastes of textiles [10-11] and home textiles [12]. In similar studies, wastes of cotton fabrics and indigo-dyed denim fabrics were dissolved in suitable solvents, then fibers were spun from them and the properties of these fibers were investigated [13-14]. Structural and 
mechanical characteristics of fabrics recycled from textile wastes and potential utilization areas [15-18], possibility of polyester/cotton blend reuse in composites [19], quality of yarn at different blend ratios [20] and possibility of recycled yarn production and fabrication parameters have been subjects of different studies [21-27]. However, studies related to investigation of fabric defects produced from recycled and original fibers are limited.

Defect formation during woven fabric formation is inevitable no matter what type of raw material is used. In order to eliminate interpretation differences in defect characterization, standards including TS471, ASTM D3990 and BS7342 were used [28]. Woven fabric defects are deviations, which occur regionally, affect fabric appearance, change fabric structure and cause special changes in regional limitation [29]. Fabric defects have been defined by Turkish Standards Institute as "defects in fabrics which are caused by the yarn, auxiliary material, labor, machinery, equipment or working method, and can be seen and evaluated with eye and impair fabric appearance" [30].

During classification of fabric rolls as the first or the second quality, different defect grading systems can be utilized. The systems, which enjoy common use, are 4-point system, 10-point system, Graniteville 78 system and The Worth Street Rules Systems. It is necessary to apply necessary quality control inspections on fabrics and conduct objective evaluation before accepting them for apparel manufacturing processes [31]. However, the 4-point, 10-point and the Worth Street Rules systems do not reflect the effect of defects due to their grading method. In 4-point and the Worth Street Rules systems, only 4 points can be allocated to a yard. In 10-point system, a yard can only get 10 points. On the other hand, the points to be attained to a yard square of fabric is determined by the fabric width in Graniteville 78 System. Moreover, defects like stains which do not deteriorate acceptability of fabrics for apparel manufacturing processes do not take points [28]. Thus, Graniteville 78 system is among the most suitable fabric grading systems for determining if the fabric is acceptable for apparel manufacturing processes. In this study, Graniteville 78 System has been adopted as it was aimed to detect irreparable defects, which negatively affect the apparel. In table 1, defect points corresponding to defect dimensions are given.

The Graniteville 78 system is a grading system that was developed by Graniteville Firm in 1975 for evaluating standard woven and knitted fabric qualities. The defect points determined by Graniteville 78 system are given in table 1 . In this system, only defects that have to be cut out from the fabric or that render the final product second quality are taken into consideration. Each yard-square or meter-square fabric can receive maximum 4 points. The maximum points that a yardsquare fabric can get is determined by the fabric width. The ninth of fabric width in inches designates the maximum defect grade. To give an example, the maximum defect point to be given to a fabric the width of which is 48 inches is $48 / 9=5.33$ or 6 [28].

Table 1

\begin{tabular}{|c|c|}
\hline \multicolumn{2}{|c|}{$\begin{array}{c}\text { DEFECT DIMENSIONS AND CORRESPONDING } \\
\text { PENALTY POINTS ACCORDING TO GRANITEVILLE } \\
78 \text { SYSTEM }[31,32]\end{array}$} \\
\hline Defect length & Penalty points \\
\hline For defects up to $23 \mathrm{~cm}$ (9 inch) & 1 \\
\hline For defects $23-46 \mathrm{~cm}$ (9-18 inch) & 2 \\
\hline For defects $46-69 \mathrm{~cm}(18-27$ inch) & 3 \\
\hline For defects $69-92 \mathrm{~cm}$ (27-36 inch) & 4 \\
\hline For defects $92-115 \mathrm{~cm}$ (36-45 inch) & 5 \\
\hline For defects $115-138 \mathrm{~cm}(45-54$ inch) & 6 \\
\hline For defects $138-160 \mathrm{~cm}$ (54-63 inch) & 7 \\
\hline
\end{tabular}

In this study, different shirting fabrics, which were produced for order in a weaving factory, which manufactures shirting fabrics from recycled cotton threads (regenerated threads, as known in the industry), and their blends, have been investigated. The aim was to identify defects that can be seen in apparel manufacturing process in fabrics produced from recycled yarns. The investigated fabrics are classified in terms of their quality according to Graniteville 78 system.

\section{MATERIALS AND METHOD}

\section{Materials}

This study has been conducted in a factory, located in Denizli province, (consisting of spinning and weaving mills), which has 315 weaving machines and produces home textiles (such as bedlinens), shirting and trouser fabrics. In the study, white shirting fabrics were produced using different weft thread blends as per orders. The constructions of weft threads are 100\% r-Cotton, $100 \%$ Cotton, 35\% PES - 65\% rCotton, $35 \%$ PES $-65 \%$ Cotton, $50 \%$ PES - 50\% r-Cotton, $50 \%$ PES - $50 \%$ Cotton. The bales of recycled fibers and slivers used during the production of yarns for the mentioned fabrics are shown in figure 1.
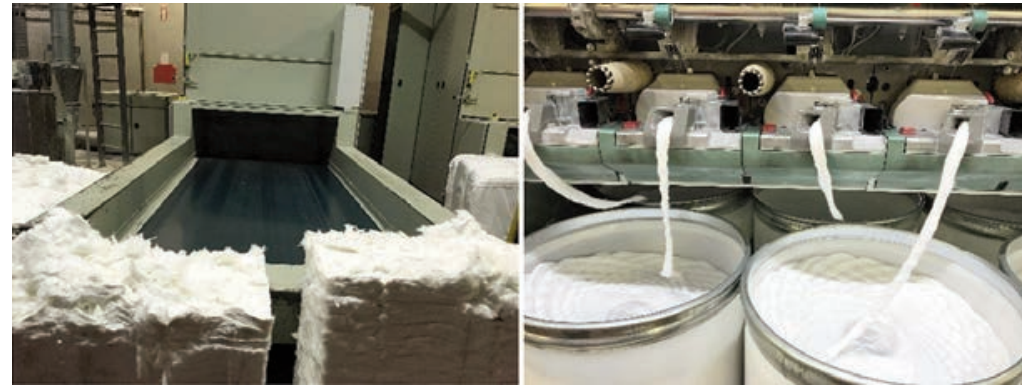

Fig. 1. Recycled fiber bales and slivers used for the production of the fabrics 
STRUCTURAL PROPERTIES OF THE FABRICS

\begin{tabular}{|c|c|c|c|c|c|c|}
\hline \multirow{2}{*}{$\begin{array}{c}\text { Fabric } \\
\text { code }\end{array}$} & \multirow{2}{*}{$\begin{array}{l}\text { Weft thread } \\
\text { raw material }\end{array}$} & \multirow{2}{*}{$\begin{array}{l}\text { Weft thread } \\
\text { NE }\end{array}$} & \multicolumn{2}{|c|}{$\begin{array}{c}\text { Density } \\
\text { (thread/cm) }\end{array}$} & \multirow{2}{*}{$\begin{array}{l}\text { Mass } \\
\left(\mathrm{g} / \mathrm{m}^{2}\right)\end{array}$} & \multirow{2}{*}{$\begin{array}{l}\text { Total } \\
\text { (mt) }\end{array}$} \\
\hline & & & Warp & Weft & & \\
\hline 1 & $100 \%$ r-Cotton & $20 / 1$ & 30 & 24 & 100 & 350 \\
\hline 2 & $100 \%$ Cotton & $20 / 1$ & 30 & 24 & 100 & 350 \\
\hline 3 & $35 \%$ PES - 65\% r-Cotton & $20 / 1$ & 30 & 24 & 100 & 350 \\
\hline 4 & $35 \%$ PES - $65 \%$ Cotton & $20 / 1$ & 30 & 24 & 100 & 350 \\
\hline 5 & $50 \%$ PES - 50\% r-Cotton & $20 / 1$ & 30 & 24 & 100 & 350 \\
\hline
\end{tabular}

The fiber structural properties of the produced fabrics are listed in table 2 . The constructions and production volumes of the produced fabrics are the same. The warp thread is 100 -denier polyester thread and plain weave structure has been adopted for all fabrics. The recycled yarns were produced in the open-end spinning section of the mentioned factory. The recycled fibers were obtained from Uşak province. The length of the polyester staple fiber is $38 \mathrm{~mm}$. In woven fabrics, both weft and warp threads influence the physical and mechanical properties of the fabrics. In this study, no changes have been made in warp density and type. On the other hand, only changes to weft threads were made.

\section{Method}

All fabrics were processed through bleaching in a wet treatment mill and were brought to the factory in white color. Before these fabrics were sent to the receiver apparel manufacturing company, they were manually inspected by using a light board. Following, the inspected fabrics were graded according to Graniteville 78 system in terms of their quality. The defects that are classified in fabric inspection sheets used in the current study can be grouped in three main classes; defects in weft direction, defects in warp direction and other defects. The defects in weft direction are full-width double wefts, half-width double wefts, full-width broken weft, half-width broken weft, stop mark, weft fiber in color, soiledgreased weft, thin-thick weft, excessive weft density. The defects in warp direction are broken warp, excessive warp density, loose-tight warp, warp fiber in color, stained-greased warp, thin thick warp, double warps, missing warp, temple mark; and other defects include slub, bad selvedge, and knot.

\section{FINDINGS}

The fabric defects which were obtained from the inspection of 2100 meters fabric were recorded into inspection sheets according to the determined defect classification. The defects in the outer $3 \mathrm{~cm}$ width were ignored. If a running meter of the fabric includes more than one defect, the greatest defect was recorded to the sheet. The inspected fabrics were graded according to Graniteville 78 system. In the fabric rolls, the obtained defects include fullwidth double wefts, half-width double wefts, full-width groups as defects in weft direction, defects in warp direction and other defects are given in table 3 .

As the weft threads are varied, it was expected that most of the defects would be in the weft direction. It can be said that the defects that are shown in figure 2 , namely, half-width broken weft, fiber in color, thinthick weft, are specific defects which develop during recycled yarn spinning. The half-width broken weft and thick-thin weft defects are caused by the quality of the recycled fibers. As the waste fabric clippings are transformed into the fiber form, loss of strength, and increase in short-length fiber content takes place. These in turn lead to decreased yarn strength which results in weft breakage during weaving. The

Table 3

\begin{tabular}{|c|c|c|}
\hline \multicolumn{3}{|c|}{$\begin{array}{c}\text { DEFECTS IN WOVEN FABRICS AND THEIR } \\
\text { POSSIBLE CAUSES [30] }\end{array}$} \\
\hline & Defect name & $\begin{array}{c}\text { Possible cause } \\
\text { of defect/Name } \\
\text { of Process }\end{array}$ \\
\hline \multirow{8}{*}{$\begin{array}{l}\text { Weft } \\
\text { defects }\end{array}$} & $\begin{array}{l}\text { Double wefts half width } \\
\text { or less }\end{array}$ & Weaving \\
\hline & Full-width Broken weft & Weaving/Spinning \\
\hline & Half-width broken weft & Spinning \\
\hline & Stop mark & Weaving/Spinning \\
\hline & Fiber in color & Spinning \\
\hline & Soiled-greased weft & Spinning \\
\hline & Thick-thin weft & Spinning \\
\hline & Excessive weft density & Weaving/Spinning \\
\hline \multirow{8}{*}{$\begin{array}{l}\text { Warp } \\
\text { defects }\end{array}$} & Broken warp & Weaving/Spinning \\
\hline & Excessive warp density & Weaving \\
\hline & Loose-tight warp & Weaving \\
\hline & Warp fiber in color & Weaving/Spinning \\
\hline & Soiled-greased warp & Weaving/Spinning \\
\hline & Thin-thick warp & Spinning \\
\hline & Double warps & Weaving \\
\hline & Missing warp & Weaving \\
\hline \multirow{3}{*}{ Others } & Slob & Weaving \\
\hline & Knot & Spinning \\
\hline & Soil/grease stain & Finishing \\
\hline
\end{tabular}




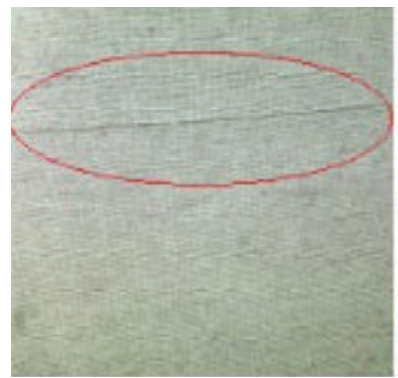

a

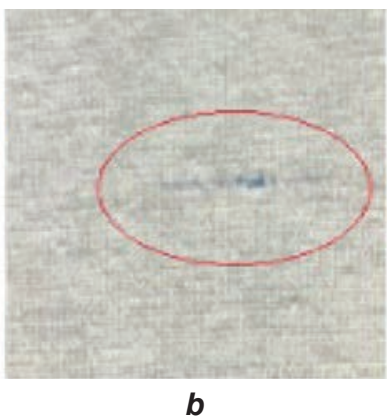

b

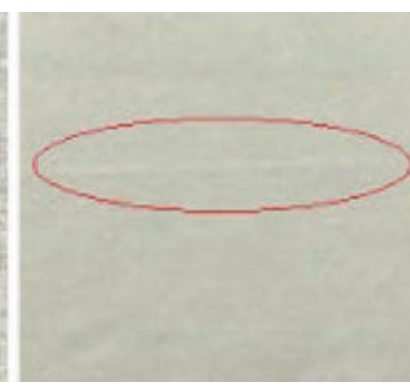

c
Fig. 2. Defects commonly found in recycled fabrics: $a$ - half-width weft; $b$ - fiber in color; $c$ - thin thick weft

bales are inspected with eye and graded according to color catalogue [33]. The first step of so-called rag pulling process, which is a mechanical fiber opening process, is sorting. This step is carried out generally manually, and presence of fibers in different colors in bales leads to this defect.

The number of defects and defect lengths which are necessary for calculating the

thin-thick weft and knot defects are also caused during fiber production. These defects may be caused by fiber opening machine settings and fiber properties. If the cylinder opening, among machine settings, is increased then feed back amount increases. On the other hand, if this opening is decreased, then the clippings cannot be fully transformed into fibers and neps occur [33]. The fiber in color defect obtained in this study is specific to recycled yarns. The clippings which are received to recycled yarn spinning mills as penalty points according to Graniteville 78 system for fabrics are six different weft threads and the length of each is $350 \mathrm{~m}$. These data are shown in table 4 for 100 r-Cotton and 100\% Cotton, 35\% PES - 65\% r-Cotton, 35\% PES - 65\% Cotton, 50\% PES - 50\% $r$-Cotton and 50\% PES - 50\% Cotton fabrics.

As the defects like stains, which do not cause the fabric to be sorted as the second quality for the apparel manufacturing process, Graniteville 78 system does not give points to such defects, which are

Table 4

\begin{tabular}{|c|c|c|c|c|c|c|}
\hline \multicolumn{7}{|c|}{$\begin{array}{c}\text { TOTAL PENALTY POINTS CALCULATED ACCORDING TO GRANITEVILLE78 SYSTEM AND SORTING } \\
\text { OF THE FABRIC ROLLS }\end{array}$} \\
\hline \multirow[b]{2}{*}{ Defect name } & \multicolumn{6}{|c|}{ Number of defects } \\
\hline & $\begin{array}{l}100 \% \\
\text { r-Cotton }\end{array}$ & $\begin{array}{l}100 \% \\
\text { Cotton }\end{array}$ & \begin{tabular}{|l|}
$35 \%$ PES - \\
$65 \%$ r-Cotton
\end{tabular} & $\begin{array}{l}35 \% \text { PES - } \\
65 \% \text { Cotton }\end{array}$ & \begin{tabular}{|l|}
$50 \%$ PES - \\
$50 \%$ r-Cotton
\end{tabular} & $\begin{array}{l}50 \% \text { PES - } \\
50 \% \text { Cotton }\end{array}$ \\
\hline Full-width double wefts & 4 & 4 & 5 & 4 & 3 & 3 \\
\hline Double wefts half width or less & 4 & 2 & 3 & 2 & 2 & \\
\hline Full-width broken weft & 1 & & & & & \\
\hline Half-width broken weft & 9 & 4 & 6 & 2 & 6 & 3 \\
\hline Stop mark & 5 & 3 & 4 & 3 & 4 & 4 \\
\hline Fiber in color & 4 & & 4 & 1 & 1 & \\
\hline Soiled - greased weft & 3 & & & 3 & & \\
\hline Thin thick weft & 5 & & 4 & & & 3 \\
\hline Excessive weft density & & 2 & & & & \\
\hline Broken warp & 5 & 5 & 4 & 4 & 1 & 4 \\
\hline Excessive warp density & & & & 1 & 1 & \\
\hline Loose-tight warp & 2 & & & & & \\
\hline Warp fiber in color & & & 1 & & & \\
\hline Soiled - greased warp & 3 & 1 & & & & 1 \\
\hline Thin thick warp & & 1 & & & & \\
\hline Double warps & & 1 & & & & \\
\hline Missing warp & & 1 & & & & \\
\hline Slub & 2 & & & 1 & 1 & 1 \\
\hline Knot & 6 & 1 & 4 & 1 & 3 & \\
\hline Soil grease stain & 3 & & & 2 & 1 & 2 \\
\hline Number of defects & 56 & 25 & 35 & 24 & 23 & 21 \\
\hline Fabric roll width (inches) & 63 & 63 & 63 & 63 & 63 & 63 \\
\hline Fabric roll length (yards) & 382.8 & 382.8 & 382.8 & 382.8 & 382.8 & 382.8 \\
\hline Total penalty points & 116 & 86 & 100 & 68 & 79 & 63 \\
\hline Evaluation & Accepted & Accepted & Accepted & Accepted & Accepted & Accepted \\
\hline
\end{tabular}




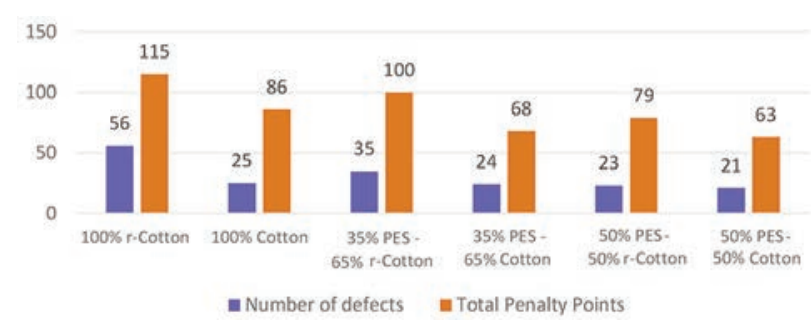

Fig. 3. The number of defects and penalty points calculated according to Graniteville 78 system

not considered as potential threats. Accordingly, defects, which have been noticed during fabric inspection that can be removed in the apparel manufacturing processes, were not given points. These defects are fiber in color, slub, soil/grease stains, soiled-greased warp, and warp fiber in color.

The total penalty points have been found as 115 for the $100 \%$ r-cotton fabric, and 86 for the $100 \%$ cotton fabric. The most common defect for $100 \%$ r-cotton fabric is half-width broken weft, and the second most common one is knot defect.

Total penalty points calculated for $35 \%$ PES - 65\% r-Cotton, and 35\% PES - 65\% Cotton are 100 and 68 , respectively. Half-width broken weft is the most common defect found in 35\% PES - 65\% r-Cotton fabric. However, as the PES yarn contributes to the strength, the frequency of half-width weft defect is lower than that in the $100 \% \mathrm{r}$-Cotton fabric.

Total penalty points calculated for the 50\% PES $50 \%$ r-Cotton fabric and the 50\% PES - 50\% r-Cotton fabric are 79 and 63, in consecutive order. Half-width broken weft is the most common defect in 35\% PES - 65\% r-Cotton fabric. However, as the PES yarn contributes to the strength, the frequency of halfwidth weft is lower than that in the $100 \% \mathrm{r}$-Cotton fabric.

In figure 3, the number of defects and penalty points calculated for all fabrics are graphically illustrated. According to this, the greatest penalty point belongs to the $100 \%$ r-Cotton fabric. In descending order, 100 points for the $35 \%$ PES - 65\% r-Cotton fabric, 86 points for the $100 \%$ Cotton fabric, 79 points for the $50 \%$ PES - 50\% r-Cotton fabric, 68 points for the $35 \%$ PES - 65\% Cotton fabric, 63 points for the $50 \%$ PES - 50\% Cotton fabric were obtained. The increase in PES content in the weft threads led to reduction in number of defects found in the recycled yarns. In table 4 , the number of defects and penalty points calculated for all fabrics are shown.

Accordingly, total penalty points calculated according to Graniteville 78 system and evaluation of the fabric roll are attached to the end of the table. All fabrics were found suitable for apparel manufacturing processes and are accepted.

\section{CONCLUSIONS}

Based on its positive effect on the price and environment, the importance of yarn and fabric production from recycled raw material is growing day by day. Nowadays, numerous producers including H\&M, Levi Strauss \& Company, Adidas, Nike and Timberland are utilizing recycled materials within frames of social responsibility projects. Global firms which produce recycled yarns and fabrics from polyester, nylon and cotton (Repreve $\AA-$-Unifi, Produced by Unifi, Repreve $\AA$, Ecocircle $®$ - Tenjin, Econyl $₫$ - Aquafil) are developing new products and use of recycled yarns and fabrics is becoming more and more common. Similarly, in our country, in Usak, one of the major textile centers, colorful cotton and yarns are produced without using any land, tractors, water, dye or any chemical agents. Second-quality yarns are sold at prices one third of their original counterparts. The clothing wastes collected from different parts of the world and Turkey are brought to Usak. After sorting in terms of color is carried out, cutting process takes place. Then, some of the wastes are transformed into the fiber form via use of rag pulling machines and used in the automotive industry as well as in bed production as felts. On the other hand, the recycled materials, which is transformed in the yarn form, is utilized in home textiles, curtains, clothing, and seat cover production. Hence, these wastes are re-utilized economically while colorful cotton is produced without using any land, tractors, water, dye or other chemicals [34]. Sorting of fabric rolls as the first and second quality is a hard task. Thus, defects that can be found in recycled fabrics are of importance. A fabric roll, which is considered as the first quality by the producer can be found as the second quality by the receiver. Fabric inspection grading systems allow everyone to speak the same language. This study has been conducted in order to determine defects that can be seen on the recycled fabrics prior to apparel manufacturing processes as well as for sorting of the fabric roll. Nevertheless, standardization of quality is needed for recycled yarns. More research study is necessary related to production of higher quality recycled yarns and fabrics more efficiently

\section{ACKNOWLEDGEMENT}

The author acknowledge the employees and directors of CNF Tekstil and Osman Canlı Tekstil who contributed to the experimental work.

\section{REFERENCES}

[1] Hawley, J.M., Economic Impact of Textile Recycling, 2008, Available at: http://krex.kstate.edu/dspace/bitstream/ 2097/1228/1/EconlmpactHawley2008.pdf [Accessed June 15, 2018]

[2] Chen, H., Burns, L.D., Environmental Analysis of Textile Products, In: Clothing and Textile Research Journal, 2006, 24, 3, 248-26

[3] Bayraktar, T., Ecology in Textiles and Apparel Manufacturing, and Ecolabels, ITKİB AR\&GE ve Mevzuat Şubesi, 2005

[4] Güngör, A., Palamutçu, S., İkiz, Y., Cotton Textiles and the Environment: Life Cycle Assessment of a Bathrobe, In: Textile and Apparel, 2009, 19, 3, 197-205 
[5] Lu, J.J., Hamouda, H., Current Status of Fiber Waste Recycling and its Future, In: Advanced Materials Research, 2014, 878, 122-131

[6] Eryuruk, S.H., Greening of the Textile and Clothing Industry, In: Fibres \& Textiles in Eastern Europe, 2012, 20, 6A, 95, 22-27

[7] Gunaydın, G. K., Can, Ö., A research on Tensile Properties of Vortex Yarns, In: Industria Textila, 2017, 68, 3, 170-175, https://doi.org/10.35530/IT.068.03.1401

[8] Merati, A.A., Okamura, M., Producing Medium Count Yarns from Recycled Fibers with Fiction Spinning, In: Text. Res. J., 2004, 74, 7, 640-645

[9] Wulfhorst, B., Textile Technology, Translation; Demir A., Torun A.R., İstanbul, 2003, 295-300

[10] Vadicherla, T., Saravanan, D., Textiles and Apparel Development Using Recycled and Reclaimed Fibers, In: Muthu S. (eds) Roadmap to Sustainable Textiles and Clothing. Textile Science and Clothing Technology, Springer, Singapore, 2014

[11] Leonas, K.K., The Use of Recycled Fibers in Fashion and Home Products, In: Muthu S. (eds.) Textiles and Clothing Sustainability. Textile Science and Clothing Technology, Springer, Singapore, 2017

[12] Rathinamoorthy, R., Sustainable Apparel Production from Recycled Fabric Waste, In: Muthu S. (eds.) Sustainable Innovations in Recycled Textiles. Textile Science and Clothing Technology, Springer, Singapore, 2018

[13] Haule, L..V, Carr, C.M., Rigout, M., Preparation and Physical Properties of Regenerated Cellulose Fibres from Cotton Waste Garments, In: Journal of Cleaner Production, 2016, 112, 5, 4445-4451

[14] Haule, L.V., Carr, C.M., Rigout, M., Investigation into the Supramolecular Properties of Fibres Regenerated from Cotton Based Waste Garments, In: Carbohydr Polym, 2016, 144, 131-139

[15] Umar, M., Shaker, K., Ahmad, S., Nawab, Y., Umair, M., Maqsood, M., Investigating the Mechanical Behavior of Composites Made from Textile Industry Waste, In: The Journal of The Textile Institute, 2017, 108, 5, 835-839

[16] Silva, R., Byrne, N., Utilization of Cotton Waste for Regenerated Cellulose fibres: Influence of Degree of Polymerization on Mechanical Properties, In: Carbohydrate Polymers, 2017, 174, 89-94

[17] Inoue, M., Yamamoto, S., Performance and Durability of Woven Fabrics Including Recycled Polyester Fibers, In: Journal of Textile Engineering, 2004, 50, 2, 25-30

[18] Larney, M., Van Aardt, A.M, Case study: Apparel Industry Waste Management: A Focus on Recycling In South Africa, In: Waste Management \& Research, 2010, 28, 36-43

[19] Zoua, Y., Reddya, N., Yang, Y., Reusing Polyester/Cotton Blend Fabrics for Composites, In: Composites Part B: Engineering, 2011, 42, 4, 4, 763-770

[20] Béchir, W., Mohamed, B.H., Béchir, A., Industrial Cotton Waste: Recycling, Reclaimed Fiber Behavıor And Quality Prediction of Its Blend, In: Textile and Apparel, 2018, 28, 1, 14-20

[21] Duru, P.N., Babaarslan, O., Determining an Optimum Opening Roller Speed for Spinning Polyester/Waste Blend Rotor Yarns, In: Textile Research Journal, 2003, 73, 10, 907-911

[22] El-Nouby, G.M., Hairiness of Yarns Made of Recycled Waste Fabric, In: J. Appl. Sci. Res., 2007, 3, 10, 972-976

[23] Halimi, T.M., Ben Hassen, M., Azzouz, B., Sakli, F., Effect of Cotton Waste and Spinning Parameters on Rotor Yarn Quality, In: Journal of The Textile Institute, 2007, 98, 437-442

[24] Kaplan, S., Göktepe, Ö., Investigation into Navel Selection for Rotor Spinning Machine Using Cotton Waste, In: Fibres \& Textiles in Eastern Europe, 2006, 14, 3, 58-62

[25] Béchir, W., Béchir, A., Mohamed, B.H., Recycling of Post-industrial Cotton wastes: Quality and Rotor Spinning of Reclaimed Fibers, In: International Journal of Advanced Research, 2015, 3, 6, 94-103

[26] El-Nouby, G.M., Recycled Yarn from Textile Waste - Part I: Recycled Yarn Hairiness, In: Egy. J. Text. \& Polym. Sci. \& Tech., 2006, 11

[27] Hasani, H., Semnani, D., Tabatabaei, S, Determining the Optimum Spinning Conditions to Produce the Rotor Yarns from Cotton Wastes, In: Industria textilă, 2010, 61, 6, 259-264

[28] Ala, D.M., İkiz, Y., Defect Detection of Velvet Bathrobe Fabrics and Grading with Demerit Point Systems, In: Pamukkale University Journal of Engineering Sciences, 2015, 21, 7, 288-295

[29] Dülgeroğlu, K.Ö., A Statistical Quality Control System in a Medium-Scale Weaving Mill: I. Control of Fabric Defects, In: Pamukkale University Journal of Engineering Sciences, 2010, 16, 3, 291-301

[30] Turkish Standards Institute, Definition and Terminology Relating to Woven Fabric Defects, Ankara, Türkiye, TS 471 ISO 8498, 2005

[31] Gürarda, A., Investigation The Relationship Between Fabric Properties And Clothing Process, In: Journals of Textiles and Engineer, 2015, 22, 99, 41-50

[32] ASTM D5430-13, Standard Test Methods for Visually Inspecting and Grading Fabric

[33] http://www.yuksel.com.tr/index2.html [Accessed May 13, 2018]

[34] http://www.milliyet.com.tr/turkiye-nin-tekstil-atigi-usak-ta-iplige-usak-yerelhaber-2339877/ [Accessed May 13, 2018]

\section{Author:}

\section{KALKANCI MIHRIBAN}

Pamukkale University, Denizli Vocational School of Technical Sciences,

Camlaraltı Mah. Fakülte Cad., no. 30, 20160, Kınıkı/Denizli, Turkey

Corresponding author:

KALKANCI MIHRIBAN

e-mail: mkalkanci@pau.edu.tr 